\title{
COMMUNITY EMPOWERMENT AS A FORM OF COMMUNITY SOCIAL RESILIENCE FACING THE IMPACT OF COVID-19
}

\author{
Rupita \\ Faculty of Social and Political Science, Tanjungpura University, Jl. Ahmad Yani Kota Pontianak \\ E-mail: rupita@fisip.untan.ac.id
}

\begin{abstract}
Small business group Usaha Bersama is commanded by PKK mothers in Sungai Bundung Laut Village, Sungai Kunyit District, Mempawah Regency. This business group empowers women in the village in producing cloth masks and disinfectants during the Covid-19 pandemic. The production of masks and disinfectant liquids is carried out together by taking advance training from competent personnel from the village officer. This research uses a descriptive qualitative approach, with analytical data being the primary data obtained by interviews and observations. Then, secondary data is obtained through review literature sourced from online news, scientific journals and books. The focus of the study is the empowering process of people with their own initiatives. The findings in this study show that this Covid-19 pandemic hit society to the lower classes, therefore in doing economic resilience their families take advantage of business opportunities namely the manufacture of disinfectants and the production of cloth masks. All of their sales were made as support for the family economy during the Covid-19 pandemic. The community groups in Sungai Bundung Laut village managed to get out of the situation of fear of Covid-19 by running productivity. All of their sales were made as support for the family economy during the Covid-19 pandemic. This business group is also a means of social resilience of the community in empowering the community through small businesses. The empowering of this group relies on local social capital that builds up between communities.
\end{abstract}

Key words: Empowerment; Community; Social Resilience; Covid-19

\section{PEMBERDAYAAN KOMUNITAS SEBAGAI BENTUK RESILIENSI SOSIAL MASYARAKAT MENGHADAPI DAMPAK COVID-19}

\begin{abstract}
ABSTRAK. Kelompok usaha kecil Usaha Bersama di komandoi oleh ibu-ibu PKK di Desa Sungai Bundung Laut, Kecamatan Sungai Kunyit, Kabupaten Mempawah. Kelompok usaha ini memberdayakan kelompok perempuan di desa tersebut dalam memproduksi masker kain dan disinfektan selama masa pandemi Covid-19. Produksi masker dan cairan disinfektan dilakukan bersama-sama dengan mengikuti pelatihan terlebih dahulu dari tenaga kompeten dari desa. Penelitian ini menggunakan pendekatan kualititatif deskriptif, dengan data analisis adalah data primer yang didapatkan dengan wawancara dan observasi. Kemudian, data sekunder didapatkan melalui literatur review yang bersumber dari berita online, jurnal ilmiah dan buku. Aspek yang menjadi fokus kajian yaitu proses berdaya masyarakat dengan inisiatif mereka sendiri. Temuan dalam penelitian ini menunjukkan bahwa pandemi Covid-19 ini melanda masyarakat hingga pada lapisan kelas bawah, oleh karena itu dalam melakukan ketahanan ekonomi keluarga mereka memanfaatkan peluang usaha yaitu pembuatan disinfektan dan produksi masker kain. Kelompok masyarakat di Desa Sungai Bundung Laut berhasil keluar dari situasi ketakutan akan Covid-19 dengan menjalankan produktivitas. Semua hasil penjualannya mereka jadikan sebagai penopang ekonomi keluarga selama masa pandemi Covid-19. Kelompok usaha ini juga menjadi sarana resiliensi sosial masyarakat dalam memberdayakan komunitas melalui usaha kecil. Keberdayaan kelompok ini mengandalkan modal sosial lokal yang terbangun antar masyarakat.
\end{abstract}

Kata kunci: Pemberdayaan; Komunitas; Resiliensi Sosial; Covid-19

\section{INTRODUCTION}

Coronavirus (Covid-19), which is endemic throughout the world, including in Indonesia, has brought new problems. It is not only a health issue, but also extends to political, economic, socio-cultural and all aspects of life. The socio-economic problem that seems significant is the problem of poverty. There is a relationship between women and conditions of poverty, where a patriarchal culture has indirectly provided boundaries for women and injustice and inequality have contributed to the closeness of women's identity to poverty (Ministry of Women's Empowerment and Child Protection, 2016). In this case, the experiences of women and men are different in poverty, where women are far behind in accessing economic resources as a gateway to eliminating various injustices in society (Ministry of Women's Empowerment and Child Protection, 2016; Niko, 2019).
In the guidelines for the community empowerment book of the Ministry of Health (2020), it is explained that the community is obliged to assist the $R T$ / $R W$ / Village officials in making efforts to prevent Covid-19 and remind each other to keep the environment clean and safe. But on the other hand, public knowledge is also limited about the right way to protect yourself from Covid-19. In some information, it is explained that the use of hand sanitizers is one way to minimize transmission of the virus to other people, when hand washing facilities are not available in one place (Kurniawati, Santosa and Bahri, 2020).

Furthermore, in the guidebook for community empowerment of the Ministry of Health (2020), it is stated that the head of the $R T / R W$ / Village Head is obliged to help poor / sick / elderly people who do not have a family. This can be done with direct assistance in the form of basic necessities or indirect assistance in the form of empowerment programs for the poor. So far, the implementation of the empowerment program policy has 
only relied on achieving target affordability, so that the evaluation of a program is not comprehensive and has the impression of "catching up".

Village officials and community members during the Covid pandemic created new social institutions that were in accordance with the needs of the village, for example, new regulations for receiving guests from outside the village area, including security and environmental activities were regulated by the village head which was decided in a village regulation. Likewise in the case of community development in villages, community development should see the activeness of local communities who are both the subject and the object of development (Proefschrift, 1974; Khan \& Khandaker, 2016). In other words, community participation in empowerment programs must be considered as an evaluation of the failure and success of a program (see also Tika, Hanafi, \& Riyanto, 2017; Niko, 2020).

Community empowerment that took place during the Covid-19 pandemic in Sungai Bundung Laut Village, Sungai Kunyit District, Mempawah Regency, West Kalimantan, namely making hand sanitizers and personal protective equipment (masks). In its implementation, the Joint Business Team which is dominated by PKK mothers in Sungai Bundung Laut Village, Sungai Kunyit District, Mempawah Regency and the poor who were affected by Covid-19, it was they who made cloth masks and disinfectant liquid amid the Covid-19 pandemic. From this the Tim Usaha Bersama will earn income by selling the products they make. This makes the community empowered in the midst of the Covid-19 pandemic as a manageable local social capital. Social capital according to Fukuyama (1996) is a condition that must be met for human development, economic development, social, political and democratic stability. Various problems and irregularities that occur in various countries, the main determinant is the low social capital that grows in society. Weak social capital will dampen the spirit of mutual cooperation, exacerbate poverty, and hinder efforts to improve population welfare.

This will later become a source of income for the economic empowerment of local communities and the impact of the Covid-19 pandemic. General development, of course, aims to improve welfare, open job opportunities, open equal access to education, and instill cultural and human values that include physical, spiritual and social welfare (Todaro, 2004). And the most important thing is to free from dependence. Therefore, according to Subair et al (2014), the perspective of community resilience is useful for understanding resource management decisions and their changes.

The relationship between the implementation of the activities of this Kelompok Usaha Bersama in terms of making cloth masks and disinfectant liquid during the Covid-19 pandemic is a form of social capital implemented in the community. According to Usman (2015), various productive collective actions are decided and designed together based on problems and needs identified together through local institutions.

If we look at the definition of social capital itself, that is, social capital is productive in nature that allows the achievement of goals together, without the common goal will not be achieved. In this discussion, related to the Tim Usaha Bersama in the manufacture of cloth masks and disinfectant liquid has a link with social capital. In the opinion of the expert, social capital is productive in nature which allows the achievement of goals with togetherness, without being a shared goal.

In research conducted by Ginting et al. (2020) states that the increasing number of people who need hand sanitizers, it is hoped that new entrepreneurs will emerge in Jungsemi Village who produce this product, either for the needs of the people of Jungsemi Village or being traded outside the region. This means that business opportunities in the midst of a pandemic by producing hand sanitizers are carried out by the community in Jungsemi Village. Furthermore, in the research conducted by Kurniawati, Santosa and Bahri (2020) which is at the same time community service activities in Terongtawah Village, Labuapi District, West Lombok Regency, it has the aim of building public knowledge and awareness in anticipating Covid-19 transmission.

Based on the research of Ginting et al (2020) and Kuniati, Santosan and Bahri (2020) it can be said that community empowerment in the midst of a pandemic is not impossible. Kurniawansyah, et al (2020) stated that the concept of handling the economic sector in the midst of the Covid-19 pandemic should be with the concept of strategic policies, namely allocation policies, distribution policies and stabilization policies.

Resilience is also closely related to an individual's ability to empower themselves. It relies on protective factors (internal and external) in resilience such as social support as well as aspects of high religiosity that can be utilized well to achieve powerlessness (Naufaliasari \& Andriani, 2013). Therefore, this study discusses how the empowerment of local communities in Sungai Bundung Laut Village, Sungai Kunyit Subdistrict, Mempawah Regency, as a form of resilience in the midst of the Covid-19 pandemic.

\section{METHOD}

The method in this research is to use a descriptive qualitative approach. Data and information that support writing are collected by conducting literature searches, observations and character interviews. Data and information used in literature search are data from scientific journals, electronic media, and some relevant literature. The data collection techniques used are: a) literature study by collecting various data from literature from online news, scientific journals and books; b) field study, namely the author goes to the field to obtain data and information 
by conducting interviews with the head of the driving team and the PKK in Sungai Bundung Laut Village, Sungai Kunyit District. Then also at the same time make observations in the field by looking at the activities carried out by the local community. The empowerment aspect explored in this paper is the relationship between the individual and his group related to the ownership of assets and the ability to utilize them.

This research activity was carried out in the community of Sungai Bundung Laut Village, Sungai Kunyit District, Mempawah Regency, West Kalimantan. The implementation of this research is to comply with the health protocols in effect during the Covid-19 pandemic. The research activity lasted only two days in the process of collecting interview data and field observations. The stages carried out in this study are as follows: (a) assessing secondary data; (b) conduct face-to-face interviews with informants; (c) selecting the research time frame in June 2020; (e) analyzing data, and (f) writing research reports.

\section{RESULTS AND DISCUSSION}

\section{Local Community Resilience: From Disaster to Empowerment}

The difficulty of finding hand sanitizers and masks has led to initiatives among community groups in Sungai Bundung Laut Village to produce their own cloth masks and disinfectant liquid. The existence of a joint business group in Sungai Bundung Laut Village, Sungai Kunyit District, Mempawah Regency is an activity that has sustainability in community social activities. In her writing, Hardilawati (2020) states that the survival strategy for small and medium enterprises can use marketing strategies through digital technology and be accompanied by improvements in the quality of the products being marketed.

Resilience is defined as a dynamic process including positive adaptation to difficult circumstances (Luthar, Ciccetti \& Becker, 2000). Then, resources become a positive factor in building individual resilience, including family resources or community organizations that encourage positive development to individuals (Fergus \& Zimmerman, 2005). This means that the resilience parameters in this paper are the power of individuals (through the Kelompok Usaha Bersama) in building the family economy.

This Usaha Bersama activity is a small business group carried out through the activity of making cloth masks by group members, including PKK mothers and the poor affected by Covid-19. This is in line with the results of research conducted by Susanto (2017) which states that strategies to increase community resilience can be done by developing human resources and by providing direct or indirect incentives (material assistance).

In a study conducted by Suryahadi, Izzati and Suryadarma (2020), it is projected that there will be an explosion of the poor in the most severe situations with an increase of $12.4 \%$ or around 8.5 million people who will become poor. The estimated increase in the number of poor people in Indonesia is due to a significant decline in projections for Indonesia's economic growth in 2020. In avoiding severe poverty, this community initiative in Sungai Bundung Laut Village has an impact on the social resilience of the community, and also activities that are carried out are activities that focus on increasing community income, where people are trained to be able to produce cloth masks and disinfectant liquids for sale.

Community participation in building social resilience independently is built to fight Covid-19. Solidarity and the desire to do something to solve problems that are experienced together arise. All came from concerns about positive cases of Covid-19. Excitement and enthusiasm to do something meaningful comes in different forms.

The social changes that have occurred caused by the Covid-19 pandemic can be said to be negative social changes because they have significant impacts on life, especially social, health, education and even the economy. Policies taken in the form of policies or programs are continuously carried out by the government in overcoming the risks that will occur after the Covid-19 pandemic.

Then, the use of local social capital is felt to be better used in the new normal conditions that have been imposed by the government. Utilization of social capital can help the microeconomic conditions which are more affected by the Covid-19 conditions. In line with Niko's opinion (2020) which states that in the face of the Covid-19 pandemic, local communities have their own ways to survive and be resilient even in the midst of an outbreak, for example they are in solidarity with each other.

Through the equipment owned by each resident, cloth masks and disinfectant liquid were finally made independently. Apart from washing hands with soap and hand sanitizer, the use of disinfectants is also needed to kill various types of viruses and bacteria, including Covid-19. Disinfectant is sprayed with to clean the surfaces of objects that most people touch, such as door handles, tables, chairs, sink taps, cupboards, and so on.

A Kelompok Usaha Bersama pioneered by PKK mothers in Sungai Bundung Laut Village which has a source of capital from PKK mothers' cash, as well as donations from donors and local government officials, then using the funds available to buy basic necessities for the production of goods -goods to be used for production. From there the funds will be managed and rotated, profits are given to members of joint business groups involved in the PKK mothers and the poor affected by Covid-19. The pioneered business capital came from donors, such as funds from the village government, this was conveyed by the informant, as follows:

The business capital used in the implementation of activities for the production needs of cloth masks and disinfectant liquid was obtained from PKK mothers' 
cash and donors from government ranks. And this has been well managed, and the profit from the sale will be the income of the team members involved, namely the team members who are poor and affected by Covid-19. So indirectly and with a broad impact, this activity has a spontaneous impact in providing additional allowances for the lives of team members who are poor and affected by Covid-19, so from that side it can provide an economic boost for the community itself.

Then, the implementation of training activities is carried out before producing and marketing products, these mothers are gathered in one room while still carrying out health and government recommendations, such as eating masks, washing hands before entering the room and maintaining a distance between one person and another person. And the implementation time was not too long and after the activity was finished, the mothers were encouraged to return to their respective homes.

The activities carried out by mothers in building this togetherness, according to Field (2014), are social capital which can be interpreted as building relationships. This means here that building relationships with others, and keeping them going over time, people are able to work together to achieve things that they cannot do alone, or which they can achieve but with great difficulty. Basically, local social capital is able to have an influence on community economic growth, health, education, welfare, even in the implementation of local or village governance.

The mandate in Permendesa No.6 of 2020 states that the use of Village Funds is managed through a participatory development mechanism by placing the Village community as the subject of development. Empowerment programs in rural areas also tend to formulate community involvement itself as both object and subject. This mandate also states that village funds are distributed to poor people in the village, either in the form of direct or indirect assistance.

Various strategies were carried out to anticipate and help provide benefits for the poor who were affected by the Covid-19 pandemic. One strategy might be to increase the social capital of the poor by channeling social assistance to those affected. In this case, the distribution of social assistance is also a form of social capital implementation in Indonesia, which means it can help the poor as a result of being affected by Covid- 19 .

The central government has indeed issued the Direct Cash Assistance program or known as BLT which is budgeted through Village funds which aims to help the poor, people who are prone to illness or people who are sick and also for people experiencing economic difficulties in the face of the Covid 19 pandemic. Mechanism This assistance for the community is carried out by the Ministry of Villages, Disadvantaged Areas and Transmigration and is also carried out by the Ministry of Social Affairs (Triyono, 2020). The government diverted part of the village fund budget for a social safety net program for residents affected by Covid-19. Direct cash assistance (BLT) taken from this village fund will target 12.3 million beneficiary households (KPM) with an index of Rp. 600 thousand per month for three months, the total budget is around Rp. 21 trillion from the state budget.

As for the use of social capital, the government has created a program using village funds by providing Direct Cash Assistance of 600 thousand for 3 months for the poor and for people whose economic conditions are affected by the Covid 19 pandemic. This direct cash assistance (BLT) program is a policy issued by the government which has a specific purpose and reason. The program appears as a manifestation of government action that contains certain values, aimed at solving public problems by utilizing available resources.

This indirect assistance to poor people can be in the form of empowerment programs with capital empowerment from village funds. This means that people must empower themselves to achieve empowerment success for them, as in many examples of empowerment programs (see Almasri \& Deswimar, 2014; Suyanto \& Pudjianto, 2015; Pertami \& Budiono, 2020).

Furthermore, according to Budiasmoro (2014), collective resilience is able to be built through the process of personal empowerment, acknowledging the group's contribution to empowerment and a process that develops systematically, progressively and sustainably. This collective resilience is closely related to the human development process. With regard to human development, basically the concepts of development should be based on capability or capability or empowerment, which contains special elements such as the ability to fulfill basic livelihood needs in the household (Sen, 1992).

Niko (2020) states that there is a need for a change in the development paradigm of the poor, for example by providing training or empowerment based on sharpening skills (ability) to empower. Then, economic problems that usually occur in general rural communities are experienced by people in various rural areas in Indonesia. Then during the Covid-19 pandemic, empowerment activities became a new challenge for community development. However, the Covid-19 pandemic has opened new business opportunities for the community, as revealed by the following informants:

At a time of a pandemic like now, we can see that the need for masks is scarce. Therefore, my team members and I were moved to produce cloth masks, which later these masks would be distributed to people who were classified as poor and sold for the needs of those in need, and the results became a source of income for team members involved in the joint venture team. these are classified as poor and affected by the Covid-19 pandemic. The disinfectant solution itself is made for the village community itself, such as in streets, stalls, places of worship, village offices, schools, and 
in people's homes. So that the village environment of Sungai Bundung Laut is sterile from viruses and various kinds of germs and bacteria.

Furthermore, Niko (2019) mentions the context of people who still maintain local customs in rural areas, tend to be isolated and live in poverty. Therefore, the empowerment of rural communities that is right on target is something that is always awaited every time the president's regime changes. However, the spirit of mutual cooperation in community development, the PKK group in Sungai Bundung Laut Village is always optimistic that there is always a bright spot in the midst of darkness, which means that there will be a way to remain socially and economically empowered even in the midst of the current Covid-19 pandemic as conveyed by the informant as follows:

Although currently still in the period of the Covid-19 pandemic, I and the Tim Usaha Bersama continue to carry out activities, but we carry out recommendations from the government by adhering to health protocols, even though the implementation of this activity involves manymembers involved, butteam members understand and understand the Health protocol and implement a Clean and Healthy Lifestyle (PHBS) and Social Distancing procedures based on recommendations from the government. In carrying out this activity we provide flexibility for team members, and here we divide 2 teams, namely members of the PKK as a cloth mask maker and community members making disinfectant liquid. In this case, these two components are needed at the time of the Covid-19 pandemic in the daily activities of rural communities.

Then, Korten (1987) states that development with an economic growth perspective results in people's dependence on a centralized bureaucracy, such as the family hope program that provides cash and non-cash assistance, which has the potential to cause community dependence. What this means is that program like this unconsciously turn off people's creativity and initiative for empowerment. Hudayana (2017) argues that the way to work directly with the community in the context of advocating programs is through an action program to make changes. The PKK community in Sungai Bundung Laut Village shared their tasks with each other in the product manufacturing process, this was conveyed by the informant as follows:

Here we share our duties, especially for members who cannot use sewing machines, after the cloth masks are finished then the masks are washed by members who cannot sew and then iron the masks also by other members. Regarding the sewing machine, it was obtained from a member who has a sewing machine in his house.

Based on the results of the interview above, it can be said that every PKK member, who is all women, is able to innovate with the knowledge they have. This is in line with what Wedaningtyas and Herdiyanto (2017) say that women's resilience can be formed from the existence of the individual's own belief values. In this case, PKK mothers in Sungai Bundung Laut Village, Sungai Kunyit District, will be able to face the Covid-19 pandemic together.

The handling of the serious impact of Covid-19 by the government is quite good, but this has not had an impact on reducing the number of poor people, both at the national and local levels during the Covid-19 pandemic. Programs originating from the Regional Budget Revenue and Expenditure Budget do not target the right target, then the funds provided for poverty reduction are still relatively small when compared to the number of poor people (Kertati, 2013).

Then, when seen in the local economic practices carried out by the community in Sungai Bundung Laut Village, Sungai Kunyit District, it can be in the form of mutual cooperation between each member of the local community in producing goods which are produced by themselves. The target market for this production activity is the surrounding community so that it will create a strong network and sense of trust among community members. This condition will encourage the public to remain vigilant but also able to innovate and remain productive despite facing various possibilities of facing the Covid-19 pandemic.

Budastra (2020) also states that what is important for the government to pay attention to, both at the central and local levels, is the protection for small and micro businesses as well as ensuring the availability of readyto-consume food and drinks for vulnerable people at the village level. These small and micro business activities are a form of local community resilience that is built from the existence of local social capital. In the end, this joint community business activity in Sungai Bundung Laut Village, Sungai Kunyit District has an impact on its members, as shown in the following interview:

The impact that this activity had on the team members was enormous. Because, not only the community, village officials also followed the order of cloth masks that we produced to be distributed to rural communities who are classified as poor and affected by Covid-19. So that this provides an advantage from our source of income and also the economy of the team members is fulfilled.

Local social capital here is the collective energy of the community (or nation) to solve common problems and is a source of motivation to achieve economic progress for the community or nation (Durkheim, 1973). In this case, it is not enough just to provide capital assistance in providing living support for the poor affected by the Covid-19 pandemic because this cannot last long. Starting with this, the implementation of activities in Kelompok Usaha Bersama is one way of increasing productivity, not 
only being guided in it, the community can also creatively make needs that are very much needed by the community in the event of being pressed during the Covid-19 pandemic, the poor are involved in Kelompok Usaha Bersama also empowered and provided with education in accordance with the Covid-19 pandemic health protocol. This activity brings benefits to group members, as shown in the following interview:

I have got a lot of benefits here (nak), with this activity, we have learned a lot about how to produce something. And I, who in fact can sew, is getting more and more trained with this activity. Not only me, but other members also agree with me. By producing these cloth masks, we have a stock of masks and people will no longer have trouble finding masks. From the sales results we get a profit that we can share equally with other team members.

Basically, social capital is placed on general social virtues, meaning that social capital can dissolve into beliefs and factors that are important for the economic health of a country, which relies on cultural roots (Fukuyama, 1996). Strengthening social capital in the face of the Covid-19 pandemic today is an alternative strategy to survive difficult times. This requires building solidarity with local communities to work hand in hand with one another.

The meaning of social capital is closely related to strengthening relationships between individuals and individuals and individuals with social groups in society, including the structure of life in the family and social groups (communities). The strength of social relationships is reflected in good behavior, a sense of friendship, mutual sympathy, and fostering close relationships and cooperation among individuals in the family who form a social group in social life (Kushandajani, 2006).

Romli (2020) states that social capital is needed in order to secure the economy of local (micro) communities, especially those who develop home industries. A strong local economy is able to strengthen the macro economy, so that the economic resilience of the family can be maintained with the income that comes from home industries. This paper explores further about social capital which is used as the basic capital of local communities in solidarity in facing the Covid-19 pandemic.

The social capital that is built between these communities give local people strength in facing the Covid-19 pandemic situation which is currently endemic. This strengthening is through the implementation of collective norms that can foster trust among community members so that social networks can be established. As the team leader said in the following interview excerpt:

The joy and sorrow that I feel in carrying out this activity is that we can still feel togetherness even in the midst of the current pandemic. But we continue to carry out these activities in accordance with current health protocols. Although they have to keep their distance from each other, this does not diminish the spirit of mutual cooperation between the members of this joint effort team. Without their enthusiasm too, this activity will not run smoothly and successfully.

Even though the local community already has the resilience capacity to carry out efforts to handle local economic and social problems independently and requires assistance and efforts to increase their capacity through empowerment, this does not mean eliminating the State's responsibility in handling local economic and social problems as a result of the Covid- 19 pandemic.

\section{CONCLUSION}

Resilience that occurs in the community of Sungai Bundung Laut Village, Sungai Kunyit District Mempawah Regency is their power in the family economy. In this case the existence of the Joint Venture Group is a means of empowerment that provides resilience to the individuals of its members. On the other hand, resources such as families and village organizations are also a means for vulnerable groups in achieving local economic power. The production and sale of cloth masks and disinfectant liquid by the Tim Usaha Bersama in Sungai Bundung Laut Village, Sungai Kunyit District, Mempawah Regency is one of the activities that greatly helps the economy of the poor affected by Covid-19. With this activity, members can train skills. This activity is very good and has sustainable community social activities in producing and selling cloth masks and disinfectant fluids. From the production of this activity, team members who are poor and affected by Covid-19 can get income for their survival during this pandemic. With good fund management, the source of capital can rotate and members can get a lot of benefits from this activity. By adhering to health protocols and maintaining distance from each other during activities, it does not diminish the morale of team members to continue producing cloth masks and disinfectant fluids. The implementation of joint business team activities in the production and selling of cloth masks and disinfectant in Sungai Bundung Laut Village during the Covid-19 pandemic was closely related to social capital, namely in the form of helping each other and working together to help the welfare of the poor affected by Covid -19 .

\section{ACKNOWLEDGMENTS}

The author would like to thank the Dean of the Faculty of Social and Political Sciences, for the support given to the author to conduct this research. The author also thanks all informants as well as various parties who contributed, either directly or indirectly, to the writing of this manuscript. Especially to Prof. Dr. Arkanudin, M.Si, the author would like to thank you for providing input on this manuscript before sending it to journal publishers. 


\section{REFERENCES}

Almasri \& Deswimar, D. (2014). Peran Program Pemberdayaan Masyarakat Desa Dalam Pembangunan Pedesaan. Jurnal El-Riyasah. 5, (1), 4152. Doi: tp:dx.doi.org/10.24014/jel.v5i1.657

Budastra, I.K. (2020). Sosial Ekonomi Covid-19 dan Program Potensial untuk Penanganannya: Studi Kasus di Kabupaten Lombok Barat. Jurnal Agrimansion. 21, (1), 48-57.

Budiasmoro, I.Y.K. (2014). Membangun Resiliensi Kolektif Masyarakat Tradisional Melalui Pendidikan Multikultural. Jurnal Pembangunan Pendidikan: Fondasi dan Aplikasi. 2, (1), 26-32.

Durkheim, E. (1973). Morality and Society. Chicago: University of Chicago Press.

Fergus, S. \& Zimmerman, M.A. (2005). Adolescent Resilience: A Framework of Understanding Healthy Development in the Face of Risk. Annual Review of Public Health. 26, 399-419.

Field, J. (2014). Modal Sosial. Bantul: Kreasi Wacana Offset.

Fukuyama, F. (1996). Trust: The social virtues and the creation of prosperity. New York: Simon \& Schuster.

Ginting, R., Huda, M., Drifanda, V. \& Affandi, R. (2020). Pemberdayaan Masyarakat Desa Jungsemi di Masa Pandemi Covid-19 Melalui Pelatihan Pembuatan Hand Sanitizer dan Pelindung Wajah. IJECS: Indonesia Journal of Empowerment and Community Services. 1, (1), 20-27.

Hardilawati, W.L. (2020). Strategi Bertahan UMKM di Tengah Pandemi Covid-19. Jurnal Akuntansi dan Ekonomika. 10, (1), 89-98. Doi: https://doi. org/10.37859/jae.v10i1.1934

Hudayana, B. (2017). Pemberdayaan Masyarakat: Bunga Rampai Antropologi Terapan. Yogyakarta: Pustaka Pelajar.

Kemenkes. (2020). Pedoman Pemberdayaan Masyarakat dalam Pencegahan Covid-19 di RT/TW/Desa. Direktorat Jenderal Kesehatan Masyarakat, Direktorat Promosi Kesehatan dan Pemberdayaan Masyarakat Kementerian Kesehatan RI. Retrieved from: https://covid19.kemkes.go.id/protokolcovid-19/pedoman-pemberdayaan-masyarakatdalam-pencegahan-covid-19-di-rt-rw-desa/\#. X2dXSGgzbIU

Kementerian Pemberdayaan Perempuan dan Perlindungan Anak. (2016). Kajian Peran Perempuan dalam Penanggulangan Kemiskinan Melalui Kegiatan Industri Rumahan. Jakarta: Staf Ahli Bidang
Penanggulangan Kemiskinan, Kementerian Pemberdayaan Perempuan dan Perlindungan Anak.

Kertati, I. (2013). Analisis Kemiskinan Kota Semarang berdasarkan Data Pendataan Program Perlindungan Sosial (PPLS). Jurnal Riptek. 7, (1), 27-38.

Khan, A. R., \& Khandaker, S. (2016). A Critical Insight into Policy Implementation and Implementation Performance. Public Policy and Administration. 15, (4), 538-548.

Korten, D. C. (1987). Community Management. Connectitut: Kumarian Press, Westaharford.

Kurniawansyah, H., Amrullah, A., Salahuddin, M., Muslim, M., \& Nurhidayati, S. (2020). Konsep Kebijakan Strategis Dalam Menangani Eksternalitas Ekonomi dari Covid-19 Pada Masyarakat Rentan di Indonesia. Indonesian Journal of Social Sciences and Humanities. 1, (2), 130-139.

Kurniawati, K. R. A., Santosa, F. H., \& Bahri, S. (2020). Sosialisasi Hidup Sehat di Tengah Wabah Virus Corona. JPMB: Jurnal Pemberdayaan Masyarakat Berkarakter. 3, (1), 58-65.

Kushandajani. (2006). Strategi Penguatan Modal Sosial Melalui Pendidikan (Belajar Dari Masyarakat Desa). Prosiding Seminar Nasional "Pendidikan IPS Sebagai Wahana Memupuk Modal Sosial Nasional", Bandung 5 Agustus 2006.

Luthar, S. S., Cicchetti, D., \& Becker, B. (2000). The Construct of Resilience: A Critical Evaluation and Giudelines for Future Work. Child Dev. 71, (3), 543-562.

Naufaliasari, A., \& Andriani, F. (2013). Resiliensi pada Wanita Dewasa Awal Pasca Kematian Pasangan. Jurnal Psikologi Industri dan Organisasi. 2, (2), 264-269.

Niko, N. (2019). Kemiskinan Perempuan Dayak Benawan di Kalimantan Barat sebagai Bentuk Kolonialisme Baru. Jurnal Pemikiran Sosiologi. 6, (1), 58-76. Doi: https://doi.org/10.22146/jps.v6i1.47467

Niko, N. (2020). Strategi Pemberdayaan Berbasis Vocational Skill pada Perempuan Miskin di Perbatasan Entikong (Indonesia-Malaysia). Yin Yang: Jurnal Studi Islam, Gender dan Anak. 15, (1), 1-18. Doi: https://doi.org/10.24090/yinyang. v15i1.3229

Romli, L. (2020). Covid-19 dan Modal Sosial. Pusat Penelitian Politik LIPI. Retrieved from: http:// www.politik.lipi.go.id/kolom/kolom-2/politiknasional/1401-covid-19-dan-modal-sosial 
Sen, A. (1992). Inequality Reexamined. New York: Sussel Sage Foundation.

Subair., Kolopaking, L. M., Adiwibowo, S., \& Pranowo, M. B. (2014). Resiliensi Komunitas dalam Merespon Perubahan Iklim Melalui Strategi Nafkah (Studi Kasus Desa Nelayan di Pulau Ambon Maluku). Journal Sosek KP. 9, (1), 77-90.

Suryahadi, A., Izzati, R. A., \& Suryadarma, D. (2020). The Impact of COVID-19 Outbreak on Poverty: An Estimation for Indonesia. Jakarta, Indonesia: The SMERU Research Institute. Retrieved from: http://www.smeru.or.id/en/content/impact-covid19-outbreak-poverty-estimation-indonesia

Susanto, A. (2017). Strategi Peningkatan Resiliensi Masyarakat Pesisir Terhadap Tekanan SosioEkologis (Studi Kasus Pesisi Kota Semarang). Jurnal Matematika, Saint, dan Teknologi. 18, (1), 11-27.

Suyanto \& Pudjianto, B. (2015). Pemberdayaan Masyarakat Menuju Desa Sejahtera (Studi Kasus Kabupaten Sragen). Sosio Konsepsia. 5, (1), 340354.
Tika, F. Y. A., Hanafi, I. \& Riyanto. (2017). Implementasi Kebijakan Pemberdayaan Masyarakat (Studi pada Pelaksanaan Program Nasional Pemberdayaan Masyarakat (PNPM) Mandiri Perkotaan di Kecamatan Batu Kota Batu). Jurnal Administrasi Publik (JAP). 1, (2), 188-196.

Todaro, M. P. (2004). Pembangunan Ekonomi Dunia ke-3 (Jilid 1, Edisi 8). Jakarta: Erlangga.

Triyono, A. (2020). Kemensos Salurkan Bantuan Sembako dari Presiden RI dalam Rangka Penanganan Covid-19. Retrieved from https://kemsos.go.id/ kemensos-salurkan-bantuan-sembako-daripresiden-ri-dalam-rangka-penanganan-covid-19

Usman, Sunyoto. (2015). Esai-Esai Sosiologi Perubahan Sosial. Yogyakarta: Pustaka Pelajar.

Wedaningtyas, P. A. M. P. P., \& Herdiyanto, Y. K. (2017). Tuah Keto Nak Luh Bali: Memahami Resiliensi Pada Perempuan yang Mengalami KDRT dan Tinggal di Pedesaan. Jurnal Psikologi Udayana. $4,(1), 9-19$. 